\section{Плоды количественного смягчения}

А.А. БАЛАБИН, кандидат экономических наук, Институт экономики и организации промышленного производства СО РАН, Новосибирский государственный технический университет. E-mail: bal_kon@mail.ru

В статье дан краткий обзор программ стимулирования экономического развития с помощюю выкупа финансовых активов (программы «количественного смягчения») в различных странах. Данные статистики свидетельствуют о том, что количественное смягчение оказывает слабое воздействие на рост валового внутреннего продукта. Однако при этом возникают и негативн рост фекты, связанные с несор дуз государственного долга, спекулятивным ростом цен на рынке уенеличением и обесцен

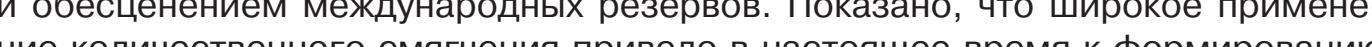
с

(1) банк, операции на открытом рынке, эмй лизация рынка ценных бумаг, фиктивный капитал, США, еврозона, Япония

- Да ведь король гольй! - сказал вдруг какой-то ребенок.

И королю стало не по себе: ему казалось, что люди правы, но он думал про себя:

«Надо же выдержать проиессию до конца»».

Г.Х. Андерсен. «Новое платье короля»

Как известно, «количественное смягчение» (quantitative easing, QE) - это общее обозначение ряда программ, предусматривающих выкуп центральными банками определенных видов финансовых активов на вторичном рынке для целей стимулирования экономики. Его широкомасштабное применение практиковали Соединенные Штаты Америки (где данная программа проводилась с ноября 2008 г. по октябрь 2014 г.), затем аналогичные программы стали осуществляться Банком Англии (с сентября 2009 г.), Банком Японии ${ }^{1}$ (с апреля 2014 г.) и в странах еврозоны

Термин quantitative easing был предложен Ричардом Вернером (ныне профессор Университета Саутгемптона) во время его работы в Японии в 1994-1998 гг. Статья (на японском языке) с таким заголовком была опубликована 2 сентября 1995 г. в The Nihon Keizai Shimbun. Правда, Банку Японии в то время не пришло в голову использовать это словосочетание для обозначения своих действий. Широкую популярность термин получил после ряда выступлений в 2008-2009 гг. главы ФРС США Бена Бернанке, пришедшего на пост из академических кругов и знакомого с работами Р. Вернера (с марта 2015 г.). Однако влияние таких программ выходит далеко за пределы стран, их осуществляющих. Затрагивает оно и нашу страну. Попробуем посмотреть на появление и результаты действия этих программ более широко, в контексте развития всей современной международной финансовой системы.

\section{События, предшествующие появлению}

\section{программ количественного смягчения}

Один из постулатов современной теории и практики государственного регулирования экономики - принцип ограниченного вмешательства государства в экономическую деятельность: если такое вмешательство и осуществляется, то преимущественно с помощью косвенных методов и инструментов. Большое распространение получили финансово-экономические меры регулирования денежного обращения, в частности регулирование центральным банком ставок по операциям рефинансирования кредитных организаций, а также проведение им же так называемых операций на открытом рынке (сделок на вторичном рынке по выкупу или продаже иностранной валюты, ценных бумаг, прав требования по кредитам и т. д.). Обе группы мер проводятся для увеличения (или уменьшения) предложения количества денег в экономике.

Перечень возможных операций центрального банка определен действующими законодательными актами, и, строго говоря всегда готов к использованию. Он дополняется внутренними нормативными документами самого регулирующего органа, отвечающего за финансовую стабильность и выбирающего технологию принятия решений при совершении операций. Определяющим является то, что центральный банк страны никак не стеснен в денежных средствах, поскольку он сам их и эмитирует. Покупка (продажа) ценных бумаг центральным банком в ходе операций на открытом рынке приводит просто к одновременному увеличению (уменьшению) бухгалтерской величины активов и пассивов его баланса на одну и ту же величину, причем эти изменения не требуют легитимации в виде каких-либо политических действий или законодательных актов (как это происходит, например при принятии государственного бюджета).

В большинстве случаев изменение ставок по операциям рефинансирования носит долгосрочное воздействие (из-за 
инерционности получения и погашения кредитов конечными заемщиками банков), а операции на открытом рынке проводятся оперативно и являются краткосрочными (охватывают от одного дня до квартала).

Обратимся теперь к ситуации, сложившейся в США в 20072008 гг. Финансовый кризис, начавшийся с неожиданного и глубокого падения рынка необеспеченных ипотечных ценных бумаг весной 2007 г., охватил большое количество финансовых и кредитных организаций, являвшихся основными их держателями ${ }^{2}$. Стандартный монетарный рецепт антикризисной помощи, использованный Федеральной резервной системой, состоял в понижении ставок рефинансирования (в частности, целевая ставка по федеральным фондам была снижена с 5,25\% годовых в августе 2007 г. до 2\% - в апреле 2008 г.) $)^{3}$.

Однако особой остроты кризис достиг осенью 2008 г. $^{4}$ В условиях паники, охватившей финансовую верхушку США, никакое уменьшение ставок на сколько угодно процентов не могло уже облегчить ситуацию. И в этой точке было задействовано «количественное смягчение». Новизна идеи состояла не в изобретении правительством и руководством ФРС новых видов банковских операций, а в том, чтобы использовать имеющийся у ФРС механизм операций на открытом рынке для проведения долгосрочного (точнее говоря, никак не ограниченного сроками) выкупа активов. Но одновременно это означало, что ФРС, выкупая активы отдельных американских компаний и государственные долги на вторичном рынке, осуществляла эмиссию денежных средств. По сути, это развязывало руки и правительству США, поскольку открывало широкие возможности для размещения новых выпусков государственных

2 Наибольшую известность получило банкротство в августе 2007 г. инвестиционного банка Bear Stearns, который являлся на тот момент пятым по величине в США. Скажем, кстати, что понятие investment bank в российском переводе лучше обозначать словами «инвестиционная финансовая компания», чтобы не возникало путаницы с российским термином «банк».

Учитывая продолжение и углубление кризиса, упомянутая ставка сни жалась ещё трижды до конца 2008 г., достигнув 0,25\%. Пересмотр ставки в сторону повышения (до 0,5\%) состоялся только 16 декабря 2015 г.

- Традиционно началом экономического кризиса в США (переросшего потом в мировой) считается 15 сентября 2014 г., когда подала заявление о банкротстве инвестиционная финансовая компания Lehman Brothers. ценных бумаг на первичном рынке и финансирования правительственной программы антикризисных мероприятий ${ }^{5}$.

Конечно, финансовые власти США, запустившие количественное смягчение, не осознавали и не добивались каких-то институциональных изменений. Во время пожара нужно гасить пламя тем, что есть под рукой. Однако факт остается фактом - кризис 2008-2009 гг. привел не к «зачистке» рынка от сомнительных активов и пассивов попавших в бедственное положение крупных компаний, а к преобразованию их в столь же сомнительные активы и пассивы ФРС и к ускоренному росту государственного долга США.

\section{Ход программ количественного смягчения}

Программа $Q E$ в США. Была начата в марте 2008 г. в связи с необходимостью срочного спасения крупнейших американских ипотечных агентств Federal National Mortgage Association (в просторечии - Fannie Mae) и Federal Home Loan Mortgage Corporation (Freddie Mac). Массовые дефолты по ипотечным кредитам и последующее обвальное падение цен на ипотечные долговые ценные бумаги поставили все ипотечные агентства на грань банкротства, они не могли более погашать свои текущие долговые обязательства. В результате покатились вниз и цены на акции этих компаний (к примеру, капитализация Fannie Mae на 31 декабря 2007 г. составляла 44 млрд долл., на середину июля 2008 г. - 11,5 млрд долл.) $)^{6}$. Основными держателями акций и ипотечных ценных бумаг агентств выступали как коммерческие банки, так и инвестиционные финансовые компании, которые в связи с этим также попали в катастрофическую ситуацию.

Приобретение акций Fannie Mae и Freddie Мас проводилось силами двенадцати федеральных резервных банков, составляющих ФРС, объем потраченных средств достиг в целом примерно 1,7 млрд долл., а сами агентства перешли под оперативное управление государственного Федерального агентства по жилищному финансированию (FHFA) [1].

Сам факт «национализации» Fannie Mae и Freddie Mac способствовал стабилизации на ипотечном рынке, программа

\footnotetext{
${ }^{5}$ Имеется в виду правительственная Troubled Asset Relief Program (TARP) ${ }^{6}$ Fannie Mae: Википедия. Версия 76651134. [Эл. ресурc]. URL: http://
} ru.wikipedia.org/?oldid=76651134 (дата обращения: 22.02.2016) 
достигла своих целей и была завершена в марте 2009 г. Однако оказалось, что участие ФРС в борьбе с кризисом на этом не закончилось. В связи с последующими событиями первый период QE получил условное сокращение QE1.

Продолжение программы (получившее обозначение QE2) началось в ноябре 2010 г. и длилось до июня 2011 г. «Вторая серия» предполагала приобретение облигаций Федерального казначейства США на сумму 600 млрд долл. в течение восьми месяцев.

И наконец, в сентябре 2012 г. ФРС запустила третью по счету программу количественного смягчения (QE3). На этот раз целью был выкуп как казначейских, так и ипотечных облигаций. Причем сроки окончания программы не устанавливались (в сообщении Комитета ФРС по открытым рынкам (FOMS) говорилось о «нескольких кварталах»), ежемесячно планировалось выкупать казначейские облигации на 45 млрд долл., ипотечные облигации - 40 млрд долл. С декабря 2013 г. на каждом последующем заседании FOMS сокращал объем закупок на 10 млрд долл., снизив в итоге ежемесячные покупки до 15 млрд долл. По факту программа была завершена в конце октября 2014 г., когда общее состояние экономики США было признано удовлетворительным.

В итоге трех этапов QE активы федеральных банков, входящих в ФРС, увеличились до 4,4-4,5 трлн долл., тогда как до кризиса 2008 г. они составляли всего 820-830 млрд долл. (рис. 1). Конечно, не весь этот объем эмиссии является «излишним»: часть эмитированных сумм обеспечивает увеличение оборота товаров и услуг в США. Вместе с тем, по разным оценкам, накопленная избыточная эмиссия в настоящее время составляет от 2,7 до 3,2 трлн долл. [2]

Программа QE в странах еврозоньл. Вообще говоря, Европейский центральный банк (ЕЦБ) с 2010 г. неоднократно подключался к проведению антикризисных мероприятий на территории ЕС. Зона ответственности ЕЦБ была ограничена поддержанием курса евро и банковских систем 19 европейских стран, входящих в валютный союз. Рефинансирование коммерческих банков осуществляется кредитованием под залог государственных ценных бумаг либо с помощью сделок «репо» (покупка гособлигаций у коммерческого банка с одновременным обязательством последнего выкупить их через определенный срок). Антикризисные изменения 2010-2012 гг. коснулись сроков операций рефинансирования (наряду с короткими сделками ${ }^{7}$ были введены операции на срок 3-6 месяцев ${ }^{8}$ ). Понятно, что такой механизм, вообще говоря, не вызывает накопления долговых обязательств на балансе ЕЦБ. Когда через несколько месяцев совершается вторая часть сделки «репо», ценные бумаги возвращаются их прежнему владельцу, а деньги - центральному банку.

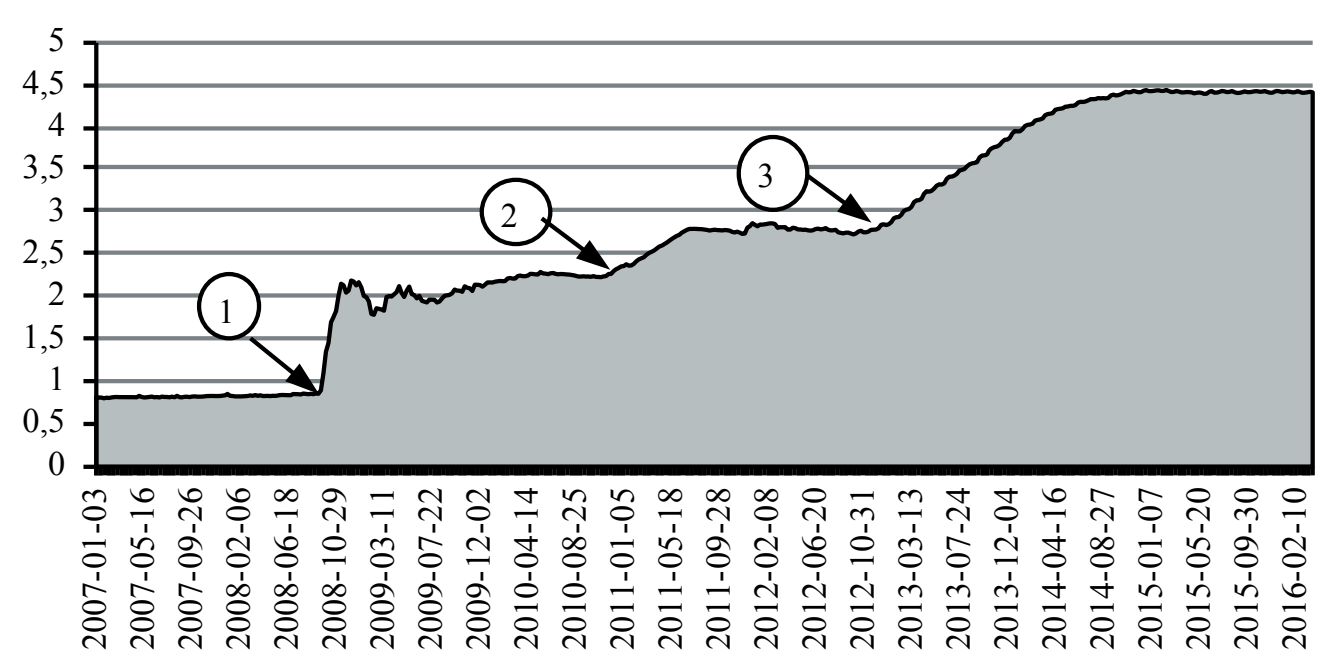

Источник: Federal Reserve Statistical Release (H.4.1 Factors Affecting Reserve Balances of Depository Institutions and Condition Statement of Federal Reserve Banks). URL: http://www.federalreserve gov/Releases/H41/Current, 2007-2016 r. (дата обрач

Рис. 1. Динамика активов Федеральной резервной системы США, трлн долл.: 1 - начало программы QE1; 2 - начало программы QE2; 3 - начало программь QE3.

В отличие от стандартных операций рефинансирования, программа количественного смягчения, начатая в марте 2015 г., предполагает приобретение ЕЦБ и национальными банками государственных долговых обязательств без указания конкретных сроков их продажи.

Количественное смягчение применяется для целей оживления экономики еврозоны. Конечно, наиболее выгодно это было бы в первую очередь странам, испытывающим в настоящее время финансовые затруднения: они получили бы возможность безболезненного увеличения своего государственного долга. Однако в этом случае ЕЦБ брал бы на себя ненадежные долги. В связи

\footnotetext{
${ }^{7}$ Main refinancing operations (MRO)

${ }^{8}$ Longer-term refinancing operation (LTRO). Отметим, что в дальнейшем максимальный срок LTRO был в удлинен, в 2014-2015 гг. он составлял
} до 48 мес. 
с этим госбумаги Греции и Кипра в список выкупаемых не попали, хотя эти страны больше других нуждаются в помощи.

Первоначально объявленный срок действия программы (март 2015 г. - сентябрь 2016 г.) был позднее продлен до марта 2017 г., либо до достижения уровня инфляции в еврозоне в размере $2 \%$. ЕЦБ ежемесячно скупает активы в размере до 60 млрд евро, при этом общий объем выкупа по первоначальному плану оценивается в 1 трлн евро. Впрочем, никто не мешает продлевать QE, увеличивая при этом объемы приобретения гособлигаций. Лишь 20\% выкупа проводит напрямую ЕЦБ, остальные 80\% - национальные центральные банки стран еврозоны

На начало марта 2015 г. нетто-активы ЕЦБ и национальных банков в сумме составляли 2,1 трлн евро, а к концу марта 2016 г. - 2,9 трлн евро, т. е. выросли на 38\% ${ }^{9}$. Если же европейская программа QE будет выполнена до конца, нетто-активы увеличатся почти в 1,5 раза. Что касается роста ВВП в еврозоне в 2015 г., то он составил, по данным Евростата, 1,5\% ${ }^{10}$, прогноз на 2016 г. $-1,7 \%{ }^{11}$. Как видим, результаты применения QE в еврозоне пока что невыразительны. Неудивительными в связи с этим выглядят и решения ЕЦБ, принятые последовательно в марте и апреле 2016 г., согласно которым объем ежемесячного выкупа увеличивается до 80 млрд евро. С июня 2016 г. начнется приобретение не только государственных и муниципальных, но и корпоративных долговых обязательств (в сумме до 70\% от объема каждого выпуска, и со сроками обрашения от полугода до 30 лет). По оценкам аналитиков Citigroup, ЕЦБ может скупить корпоративные облигации на 550 млрд евро. По подсчетам JPMorgan, ЕЦБ будет приобретать корпоративные долги на 12 млрд евро в месяц [3].

Программы $O E$ в Японии. Япония является родоначальником программ выкупа финансовых активов государственным банком. В связи с низкими темпами роста японской экономики с 1999 г. Банк Японии поддерживал ставки рефинансирования почти

${ }^{9}$ Consolidated financial statement of the Eurosystem. [Эл. pecypc]. ECB Statistical Data Warehouse. URL: http://sdw.ecb.europa.eu/browseSelection do? DATASET=0\&BS_ITEM=T000\&node=bbn129 (дата обращения: 10.04.2016). 10 URL: http://www.banki.ru/news/lenta/?id=8684325 (дата обращения: 10.04.2016).

11 URL: http://ria.ru/world/20160310/1387827729.html (дата обращения: 10.04.2016) на нулевом уровне. Однако даже сверхнизкие ставки не стимулировали экономическое развитие. Поэтому с марта 2001 г. началось осуществление программы выкупа Банком Японии краткосрочных государственных облигаций. В дальнейшем Банк Японии начал приобретать некоторые другие финансовые инструменты (имеющие залоговое обеспечение), а позже - акции коммерческих компаний. Несмотря на увеличение активов коммерческих банков с 5 до 35 трлн йен, влияние программы на экономический рост было крайне незначительным, и через четыре года она была свернута.

Вторая попытка применения QE началась в мае 2013 г., когда, в связи со сменой финансового курса новым правительством Японии, было принято решение о выкупе Банком Японии государственных и ипотечных ценных бумаг на 60-70 трлн йен (600-700 млрд долл.) каждый год в течение двух лет. То есть ежегодные плановые объемы выкупа приблизительно соответствовали американской QE2, хотя ВВП Японии в 2013 г. был в 3,4 раза меньше ВВП США.

Доклад Банка Японии [4] по итогам программы QE в 2013 2014 гг. свидетельствует о том, что, несмотря на выполнение планов по выкупу ценных бумаг, удалось достичь весьма слабого роста экономики. Отмечается, что наблюдалось значительное увеличение цен на фондовом рынке (с момента начала программы выкупа активов индекс Токийской фондовой биржи (ТОРІХ) вырос на 40\%), ослабление йены (она обесценилась на $24 \%$ по отношению к доллару), средняя ставка по десятилетним облигациям японского правительства снизилась с $0,7 \%$ до $0,4 \%$. Что касается роста реального ВВП, то вместо ожидавшегося прогнозного прироста в 6-16 трлн йен был получен прирост всего в 1 трлн йен.

В ноябре 2014 г. Банк Японии принял новое решение об увеличении объемов выкупа в 2015 г. до 80 млрд йен ${ }^{12}$. А в ноябре 2015 г. было решено продлить QЕ в Японии, с выкупом в объявленных объемах в 2016 г. и в последующие годы до достижения инфляции на уровне $2 \%{ }^{13}$.

12 URL: http://tradersroom.ru/translation/49605-2014-10-31-05-37-48 (дата обращения: 12.04.2016).

${ }^{13}$ URL: http://www.bbc.com/russian/news/2015/11/151119_japan_monetary policy (дата обращения: 12.04.2016) 
Таким образом, количественное смягчение привело к тому, что за период с мая 2013 г. по апрель 2016 г. активы Банка Японии выросли в 2,34 раза $^{14}$, а государственный долг достиг $243 \%$ от ВВП ${ }^{15}$. В то же время в 2013 г. прирост ВВП (по паритету покупательной способности) составил 0,8\%, в 2014 г. - 1,6\%, в 2015 г. $-0,6 \%{ }^{16}$.

Мы не претендуем на обзор всех эффектов и последствий программ количественного смягчения. Отошлем любознательного читателя к обзорной литературе на эту тему (см, например [5-9]). Остановимся на принципиальном вопросе - куда же подевались все те денежные средства, которые так щедро эмитировали центральные банки? Понятно, что первоначально деньги оказались на счетах тех лиц, которые ранее владели выкупленными ценными бумагами. Это прежде всего крупные банки и их клиенты (инвестиционные и страховые компании, пенсионные фонды и т. д.).

По логике авторов QE, это должно было облегчить доступ компаниям реального сектора к кредитам и тем самым стимулировать их деловую активность. Но увеличение дешевых денежных средств вовсе не означает, что банк или иной инвестор будут автоматически и пропорционально расширять круг кредитуемых лиц. Природа кредитования предполагает соблюдение принципов платности, возвратности, срочности. Если прежние клиенты «закредитованы» и «перекредитованы», если не появилось новых клиентов и/или направлений ведения бизнеса в реальном секторе, если каждый следующий клиент выглядит всё менее надежным - лучше воздержаться от кредитования. «Не имеет смысла поливать почву, если в ней нет семян растений. А если семена есть, то, может, это сорняки? Пусть сначала появятся хоть какие-то признаки роста - тогда и начнем поливать», - вот ход рассуждений банкира ${ }^{17}$.

${ }^{14}$ Рассчитано по данным Bank of Japan Statistics (Bank of Japan Accounts 2013-2016). URL: http://www.boj.or.jp/en/statistics/boj/other/ac/index.htm (дата обращения: 12.04 .2016 )

URL: http://www.vestifinance.ru/videos/25889 (датаобращения: 12.04.2016). ${ }^{16}$ URL: https://www.cia.gov/library/publications/the-world-factbook/geos/ ja.html (дата обращения: 12.04.2016)

17 Кстати говоря, эта логика рассуждений относится к любым институциональным инвесторам, невзирая на национальную принадлежность, См., например, небольшую подборку мнений российских банкиров по поводу кредитования предприятий малого и среднего бизнеса в настоящее время в России [10]
И вместе с тем деньги должны «работать» - пусть хотя бы под небольшой процент, но должны. В неблагоприятных экономических условиях, когда неясны перспективы роста, вариантов сравнительно безопасного вложения средств немного:

1) реинвестировать свободные денежные средства в имеющиеся на рынке и новые выпуски государственных ценных бумаг (в этом случае следствием будет быстрый рост государственного долга при одновременном уменьшении доходности вложений);

2) приобрести корпоративные ценные бумаги, имеющие приемлемую надежность и ликвидность (в этом случае результатом будет быстрый рост цен на биржевом рынке ценных бумаг);

3) экспортировать капитал за рубеж в виде краткосрочных портфельных инвестиций (в данном случае это найдет отражение в увеличении объемов приобретения ценных бумаг на зарубежных биржах в спекулятивных целях, арбитражных сделках на валютном рынке, в росте международных резервов других государств и т. п.).

\section{Последствия количественного смягчения для рынка ценных бумаг}

Остановимся более подробно на влиянии программ количественного смягчения на фондовый рынок. Сделаем это на примере США. Рисунок 2 демонстрирует, как менялась капитализация рынка акций по отношению к валовому внутреннему продукту этой страны. С известной долей условности можно принять, что ВВП характеризует динамику развития реальной экономики, а рыночная капитализация - отражает изменение представлений о стоимости субъектов экономики, «производящих» этот ВВП.

Движение рынка акций всегда имело выраженный циклический характер. В 1980-е и в 1990-е годы циклы в движении цен акций в основном совпадали с динамикой ВВП, имея при этом более сильную амплитуду. В периоды экономического подъема спекулятивные ожидания участников рынка ценных бумаг «толкают» цены вверх гораздо быстрее, чем растет реальный сектор экономики (это хорошо видно на примере 1995-1999 гг.) И наоборот, спад в реальном секторе сопровождается гораздо более быстрым и глубоким падением цен на рынке акций (2000-2002 гг.) 


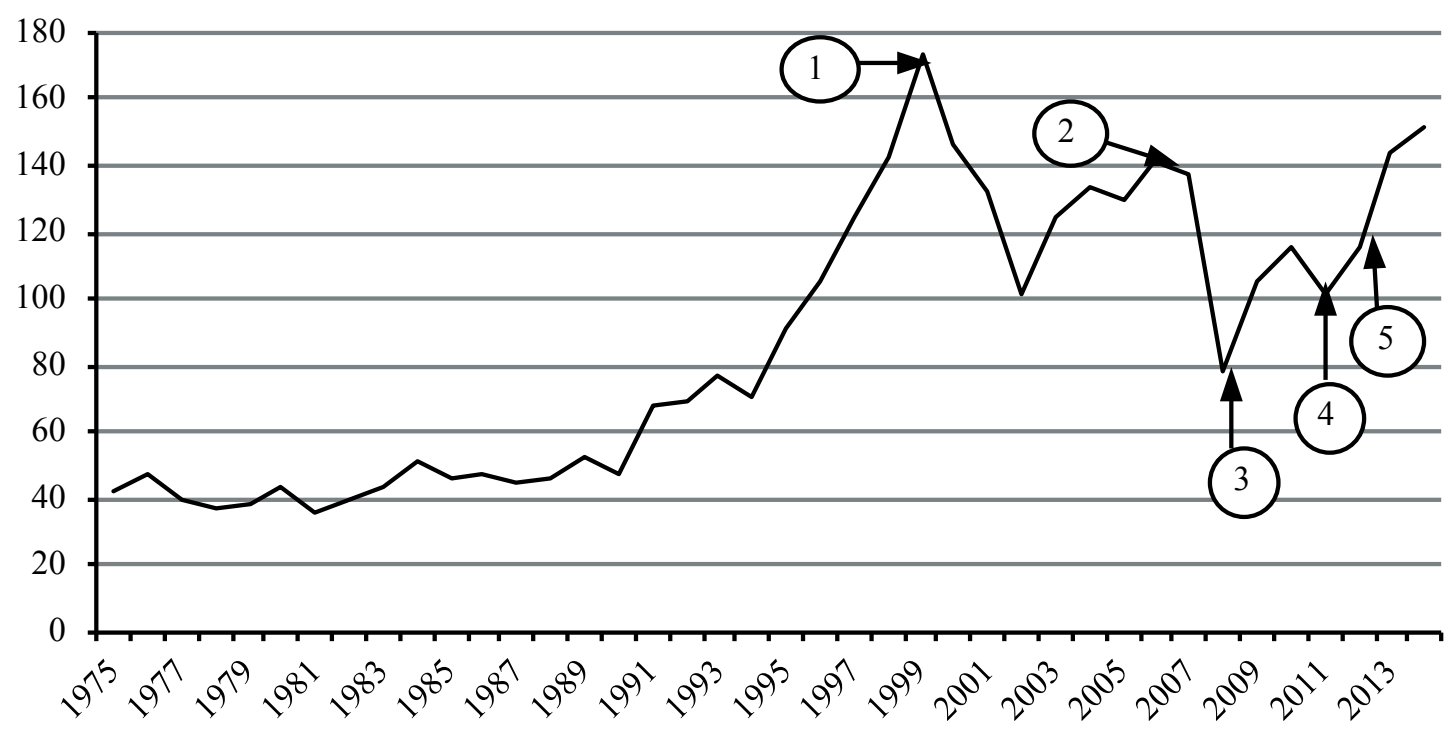

Источник: World Bank. URL: http://data.worldbank.org/indicator/CM.MKT.LCAP. GD.ZS. 1975-2014 гг. (дата обращения: 02.04.2016).

Рис. 2. Отношение рыночной капитализации ${ }^{18}$ к валовому внутреннему продукту США в 1975-2013 гг.

$\%$ на конец соответствующего года: 1 - начало кризиса на рынке высокотехнологичных акций («кризис доткомов», 2000 г.); 2 - начало финансового кризиса в США (2007 г.); 3 - начало программы QE1; 4 - начало программы QE2; 5 - начало программы QE3

Итогом циклических кризисных явлений было до недавнего времени «сдувание пузыря» на рынке ценных бумаг и восстановление более-менее нормального соотношения между ВВП и рыночной капитализацией (что мы и видим, например, в конце 2002 г.). Кризис выполнял свою благотворную роль, насильственно осуществляя отрицательную переоценку акционерного капитала.

Выполнение программ количественного смягчения почти «отменило» эту циклическую динамику. При слабых темпах увеличения ВВП США в 2009-2014 гг. рыночная капитализация бурно росла. Каждый последующий этап QE «подстегивал» уже

${ }^{18}$ Как известно, рыночная капитализация представляет собой произведение всего количества выпущенных акций на их биржевые цены, отражая тем самым представления биржевых инвесторов о суммарной стоимости компаний, акции которых котируются на бирже. При этом Всемирный банк не включает в показатель рыночной капитализации акции инвестиционных и паевых фондов и холдингов, занимающихся только портфельным инвестированием. С учетом названных юридических лиц капитализация (а, следовательно, отношение капитализации к ВВП) было бы ещё выше. не столько реальное производство, сколько его «бумажное выражение» на фондовом рынке. В результате отношение капитализации к ВВП, упавшее ниже $80 \%$ в 2008 г., под воздействием притока «дешевых» денег от количественного смягчения достигло к началу 2015 г. более 150\%. Для сравнения: в январе 2007 г., перед тем как «лопнул пузыры» американских ипотечных ценных бумаг (событие, которое во многом спровоцировало позднее мировой финансовый кризис), рынок акций США составлял «всего» 141\% от ВВП.

На сегодняшний день рынок акций США выглядит так, как будто экономика этой страны находится на стадии оживленного подъёма. Фондовый рынок частично абсорбировал излишек ликвидности и тем самым дает явно завышенные оценки стоимости компаний реального сектора. Причем сформировавшийся на биржевом рынке акций «пузырь» касается не какого-то конкретного сектора экономики, а всех ведущих компаний США.

\section{Влияние программ QE}

\section{на международные резервы}

Напомним, что основы современных международных валютно-финансовых отношений были заложены в 1944 г. на БреттонВудской международной конференции. Суть ее решений состояла в том, что только одна, наиболее устойчивая валюта мира (доллар США) сохраняла твердую привязку к определенному весовому количеству золота. Остальные валюты, в свою очередь, были привязаны к золотому содержанию только косвенно, через обмен на доллар США. Бреттон-Вудская валютно-финансовая система просуществовала до 1971 г., когда США отказали Франции в обмене имеющихся у той долларов на золото. С тех пор тонкая ниточка, которая связывала валюты всех стран с материальновещественным миром товаров и услуг, была разорвана.

Последующие решения международной Ямайской валютной конференции 1973-1976 гг. просто констатировали сложившееся положение:

- было официально отменено золотое содержание валют («золотой стандарт»);

- курсы валют стали зависеть от соотношения спроса и предложения на них («плавающий» курс валют);

- было выбрано место, где будет находиться «в одной корзинке» некоторое количество валют разных стран, для проведения 
итоговых взаиморасчетов между ними (Международный валютный фонд - МВФ);

- придуман механизм взаиморасчетов с помощью специально сконструированной расчетной валюты МВФ (специальные права заимствования - SDR).

На сегодняшний день, несмотря на обилие мудрёных терминов и важных финансовых институтов, современный валютный рынок напоминает большой базар. Каждая страна предлагает свои товары и услуги и продает их за расчетные единицы, которые сама же и выпускает. Но если на этом базаре имеются более богатые и развитые в экономическом отношении страны (будем называть их странами-доминантами), другие государства готовы принимать в оплату своих товаров и услуг также и валюту страндоминантов. Они готовы накапливать «чужую» валюту в расчете на будущие покупки и расплачиваться ею со всеми остальными контрагентами, также готовыми использовать валюту страныдоминанта для взаиморасчетов.

В связи с этим страна-доминант получает определенное преимущество перед остальными участниками валютного рынка. Доминант может выпускать в оборот большее количество собственной валюты, чем требуется для продажи своих же товаров и/или услуг, поскольку эта валюта используется многими другими участниками рынка в качестве средств платежа и накопления. Иначе говоря, с молчаливого согласия сторон национальная валюта доминанта становится резервной для других участников рынка.

Чем больше развивается международная торговля в третьих странах, тем больше требуется резервной валюты для обслуживания оборота. Однако одновременно с этим объемы резервной валюты, находящейся в обращении и в резервных накоплениях, начинают превышать её количество, необходимое для приобретения товаров и услуг, производимых в стране-доминанте. Чем в большей степени валюта выполняет функции резервной, тем меньше она обеспечена реальными потоками товаров и услуг страны-доминанта $^{19}$. Понятно, что программа количественного смягчения, осуществляемая в неумеренных объемах банком-эмитентом резервной валюты, еще более усугубляет это несоответствие.

19 Указанное несоответствие известно в экономической науке как «парадокс Триффина».
В конце третьего квартала 2015 г. общая величина официальных валютных резервов (по всем странам) составляла 6,6 трлн долл. Из них активы, номинированные в долларах США, составляли $64,0 \%$, в евро - 20,3\%, в фунте стерлингов $-4,7 \%$, в японской йене $-3,8 \%$, в канадском долларе - $1,9 \%$, в австралийском долларе $-1,8 \%$, в швейцарском франке - 0,3\% ${ }^{20}$. Добавим, что некоторые страны (в частности, КНР) не раскрывают структуру своих резервов, эти так называемые unallocated reserves составляют (в пересчете на доллары США) еще 4,6 трлн долл.

Что касается наличной валюты, то, по некоторым данным, от трети до половины напечатанных долларов США уходит за пределы страны ${ }^{21}$.

Государство, имеющее возможность «транслировать» эмиссию своей валюты на зарубежные рынки капитала, товаров и услуг, получает значительные дополнительные выгоды (так называемый сеньораж). Тем более выгодно, если данная валюта оседает на долгий срок в международных резервах других государств и в накоплениях частных лиц.

Что касается количественного смягчения, то его влияние на международные резервы можно сформулировать следующей логической цепочкой: усиление предложения резервной валюты страной-доминантом в ходе $\mathrm{QE}$ - понижение курса резервной валюты относительно других валют - повышение цен (выраженных в резервной валюте) на товары и услуги других стран - увеличенный приток резервной валюты в другие страны - формирование положительных сальдо платежных балансов этих стран рост международных резервов этих стран через стандартные механизмы их пополнения. Верно и обратное: завершение QE будет негативно влиять (и влияет) на величину международных резервов других стран.

Отметим, что выстроенная логическая цепочка не является неизбежностью. Это не закон. К примеру, если другой доминант предпримет аналогичные действия по количественному смягчению,

${ }^{20}$ Composition of Official Foreign Exchange Reserves (COFER), 2015, quarte III. URL: http://data.imf.org/regular.aspx?key=60212443 (дата обращения: 09.03.2016)

${ }_{21}^{21}$ Доллар США. Википедия. Версия 76737734. [Эл. ресурc]. URL: http:// ru.wikipedia.org/?oldid=76737734 (дата обращения: 25.02.2016) (данные мною не проверены. - А.Б.). 
он может добиться равновесия на рынке валют, попытавшись снизить с помощью QE курс собственной валюты ${ }^{22}$. Или же власти другой страны снижают налоги и экспортные пошлины, меняют правила валютного регулирования и ослабляют масштабы изъятия валют стран-доминантов, стимулируют расходование иностранной валюты в целях роста производства и тем самым не допускают формирования слишком больших резервов.

К сожалению, общепринятой является точка зрения, что значительные международные резервы говорят о большом запасе прочности стран, их накопивших. Вообще говоря, всякий резерв - это отвлечение ресурсов от текущей деятельности, это непостроенные заводы, непроложенные дороги и невысокие зарплаты. Оправданием для существования резерва может быть только одно - постоянство и повышение надежности функционирования объекта в условиях неопределенности, хотя бы и за счет снижения эффективности его действия. Но если ваш резерв существует лишь в виде нескольких записей на счетах некоего зарубежного финансового учреждения, которые могут быть аннулированы или заблокированы как раз в трудной ситуации - это уже никакой не резерв, а просто бессмысленный вычет из текущих расходов. Чтобы воспользоваться таким «резервом», как минимум необходимо сохранять нейтральные отношения с хозяином финучреждения.

Приведем характерный пример из недавнего прошлого. Упомянутое выше спасение Fannie Mae и Freddie Mac в ходе проведения американской QE1 имело огромное значение для многих государств, хранивших свои международные резервы в облигациях этих компаний, номинированных в долларах США. В частности, по состоянию на 01.01.2008 г. инвестиции Банка России (который в силу закона управляет международными резервами России) в облигации трёх американских ипотечных агентств (FHLB, Fannie Mae и Freddie Mac) составляли 100,8 млрд долл. (2475 млрд руб.) ${ }^{23}$. Отметим, что в течение предшествующего 2007 г. вложения в ипотечные облигации США активно наращивались (по сравнению с январём 2006 г. они выросли в 2,5 раза).

\footnotetext{
${ }^{22}$ В последнее время вошел в моду термин «инфляционная война».

${ }^{23}$ Отчет Банка России за 2007 г. С. 147. [Эл. ресурc]. URL: http://www.cbr.
} ru/publ/God/ar_2007.pdf (дата обращения: 06.04.2016).
Международные резервы России на 01.01.2008 г. составляли 478,8 млрд долл. Таким образом, учитывая последующие события осени 2008 г., более 20\% международных резервов России потенциально могли быть попросту списаны в случае банкротства вышеуказанных американских компаний. Неудивительно, что, счастливо избежав опасности благодаря ФРС, Банк России в январе 2009 г. с облегчением расстался с этими ценными бумагами ${ }^{24}$. Заметим, что это не последний и не единственный элемент вложений нашей страны за рубежом (подробнее см. [11]) Не нужно винить Банк России. Просто это говорит о нынешней эфемерности любых международных резервов, по большей части номинированных в резервных валютах.

В странах, попавших в трудное экономическое положение и столкнувшихся с высокой инфляцией, происходит «бегство» от национальной валюты в резервные. Это приводит к парадоксальным ситуациям. Приведем пример современной Украины, в которой по состоянию на март 2015 г. объем накопленной иностранной валюты у юридических и физических лиц составлял 97 млрд долл. ${ }^{25}$ При этом вся антикризисная кредитная программа помощи Украине со стороны МВФ, принятая в марте 2015 г., предусматривает выделение всего 17,5 млрд долл. в течение четырех лет ${ }^{26}$

\section{Куда девать избыточный финансовый капитал?}

Неумеренное использование программ количественного смягчения привело, с одной стороны, к существенному накоплению фиктивного капитала, с другой - к раздуванию государственного долга. И, к сожалению, эта проблема является общей не только для стран-доминантов, применявших и применяющих количественное смягчение, но и для всего финансового мира.

Весьма необычной и романтической представляется идея популярного ныне экономиста Т. Пикетти о введении мирового налога на капитал [12]. Даже сам Пикетти называет свое пред-

24 Об этом (не побоюсь этого слова) стыдливо было указано мелким шрифтом в примечании к основному тексту следующего годового отчета Банка России (см. Отчет Банка России за 2008 г., С. 83, (сноска 3). URL: http://www.cbr.ru/publ/God/ar_2008.pdf (дата обращения: 06.04.2016).

${ }^{25}$ Данные Национального банка Украины. URL: http://www.bank.gov.ua/ doccatalog/document?id=19208377 (дата обращения: 09.03.2016).

${ }^{26}$ Сообщение TACC от 13.03.2015. URL: http://tass.ru/ekonomika/1827219 (дата обращения: 10.04.2016). 
ложение «полезной утопией» [12. С. 520], ведь о внедрении такого налога должны были бы договориться все страны без исключения. По мысли автора идеи, налог должен иметь прогрессивный характер, касаться всего совокупного имущества без исключения, а ненулевые ставки налогообложения начинаться с весьма большой величины, например, с 1 млн евро. Для сверхкрупных состояний (более 100 млн евро) ставки могут достигать максимума в $2 \%$ или даже выше. Автор полагает, что проблема «чрезмерного» государственного долга может быть решена тем, что на его погашение и будет направляться взимаемый прогрессивный налог на капитал. Таким образом, одновременно произойдет уменьшение и избыточного финансового капитала, и нереального к взысканию госдолга.

Доведем «мысленный эксперимент» Пикетти до логического завершения. Если все участники затянувшейся игры в определенный момент времени признают фиктивность части накопленных ими финансовых активов и взаимных долгов, почему бы им не договориться об их единовременном списании? Ведь договариваются же об этом, например, по отношению к Кипру, Греции, Украине или Афганистану. Почему же этого нельзя представить по отношению к США или Японии?

Уверен, что кое-кто из читателей имеет в составе своих личных «резервов» некоторое количество купюр с портретами зарубежных президентов или королей. И даже понимает, что эти символы экономической мощи государств, их выпустивших, в своей сумме превышают объемы реальных ценностей, которые «генерирует» экономика этих государств. Но добровольно отказываться от денежных знаков - не хочет и не будет (как, впрочем, и автор этих строк). Это означало бы, подобно глупому ребенку из андерсеновской сказки, признать голым короля, выпустившего купюры. И одновременно - признать раздетым самого себя, поверившего в мнимые королевские богатства.

Если же говорить всерьёз, никто не может дать твердого и однозначного ответа о перспективах развития программ QE в различных странах и о возможности преодоления их последствий. Из предшествующего хронологического описания событий видно, что каждая последующая «доза количественного смягчения» действует всё более слабо, что делает необходимым увеличение объёмов QE или продления сроков его действия
Часть политических, финансовых и научных кругов считает, что в целом всё сделано и делается правильно, и через некоторое время инфляция «съест» накопленные суммы «бумажных» активов, «всё само собой рассосётся». Другие полагают, что необходимо переходить от использования «старых ценностей», выраженных в резервных валютах, к «новым» валютам, в большей степени обеспеченным выпуском товаров и услуг. Третьи, памятуя о происхождении бумажных денег, запасаются золотом и другими драгоценными металлами. Четвертые, не дожидаясь признания нереальности накопленных ими богатств, пытаются приобрести или построить предприятия, технологии, природные ископаемые. Или, на худой конец, прикупить «вечных ценностей», вроде произведений искусства или уникальных драгоценностей. Выбор остается за нами.

\section{Литература}

1. Бочкарева Т. Казначейская ипотека //Ведомости. - 2008. - 8 сент. 2. Auerbach R. A Few Things the Fed Has Done Wrong // Huffington Post. 2014. - Sept. 23. URL: http://www.huffingtonpost.com/robert-auerbach/afew-things-the-fed-has- b 5863738.html

3. Базанова Е. ЕЦБ на нуле //Ведомости. - 2016. - 22 апр.

4. Quantitative and Qualitative Monetary Easing: Assessment of Its Effects in the Two Years since Its Introduction //Bank of Japan Review. - 2015. - May URL: http://www.boj.or.jp/en/research/wps_rev/rev_2015/data/rev15e03.pd 5. Roche C. Understanding Quantitative Easing (February 10, 2014). URL: http://papers.ssrn.com/sol3/papers.cfm?abstract_id=2397992

6. Ratzscher M., Duca M., Straub R. A Global Monetary Tsunami? On the Spillovers of US Quantitative Easing. - 2012. - 19 oct. URL: http:// papers. ssrn.com/abstract $=2164261$

7. Joyce M., Lasaosa A., Stevens I., Tong M. The Financial Market Impact of Quantitative Easing // Bank of England Working Paper. - 2015. - № 393. URL: http://papers.ssrn.com/abstract=1638986

8. Hudson M. US 'Quantitative Easing' is Fracturing the Global Economy. Bard College Levy Economics Institute Working Paper - 2010. - № 639. URL: http://papers.ssrn.com/abstract=1713852

9. Koepke R. What Drives Capital Flows to Emerging Markets?// IIF Working Paper. -2015. - 23 apr. URL: https://www.iif.com/publication/capital-flows/ what-drives-capital-flows-emerging-markets-2

10. Павлова О., Букатин В. Повернуться лицом// Эксперт-Сибирь. 2016. - № 13-14 (473). - С. 8-10.

11. Алексеев А. В., Дементьев Н. П. Российские внешние активы и обязательства: пора собирать камни//ЭКО. - 2016. - № 3. - С. 108-125. 12. Пикетти Т. Капитал в XXI веке. - М.: Ад Маргинем Пресс, - 2015. $592 \mathrm{c}$ 